\title{
Mandatory Requirements as a Substantive Basis for Control and Supervisory Activities and a Factor in the Effectiveness of Economic Activities
}

\author{
Submitted 06/06/20, 1 st revision 03/07/20, 2nd revision 18/08/20, accepted 15/09/20 \\ Shmaliy O.V. ${ }^{1}$, Grechkina O.V. ${ }^{2}$, Dushakova L.A. ${ }^{3}$, Shuaypova P.G. ${ }^{4}$, \\ Vasilyeva G.A. ${ }^{5}$, Voronko L.B. ${ }^{6}$
}

\begin{abstract}
:
Purpose: The purpose of this study is to determine the meaning of mandatory requirements as the subject basis of control and supervisory activities and a factor in the effectiveness of economic activities.

Design/Methodology/Approach: In order to achieve this goal in the work is, use the following general and private-scientific methods: dialectical, logical, systematic and comprehensive analysis, comparative -legal, legalistic.

Findings: The article examines the questions of the legal structure of mandatory requirements. The necessity of isolating this legal phenomenon in the general architectonics of legal regulation of control and supervisory activities, as well as in the general array of peremptory norms in order to ensure the legal certainty of the subject basis of control and supervisory activities, is substantiated. The paper defines the content and main characteristics of the mandatory requirements. As a result of the study, it is concluded that there is an active process of formation of legislation on mandatory requirements as a component of the general system of legislation on control and supervisory activities.
\end{abstract}

Practical Implications: Improving the legal mechanisms of control and supervision of production will allow to achieve the improvements I have the relationship of government and

\footnotetext{
${ }^{1}$ Head of the Department of Administrative and Information Law, Russian Academy of National Economy and Public Administration under the President of the Russian Federation, Moscow, Russian Federation, shok93@yandex.ru

${ }^{2}$ Professor of the Department of Administrative and Information Law, Russian Academy of National Economy and Public Administration under the President of the Russian Federation, Moscow, Russian Federation

${ }^{3}$ Head of the Department of Administrative and Service Law, South Russian Institute of Management of the Russian Academy of National Economy and Public Administration under the President of the Russian Federation, Rostov-on-Don, Russian Federation

${ }^{4}$ Head of the Department of State and Legal Disciplines, Rostov Institute (branch) of the AllRussian State University of Justice RPA of the Ministry of Justice of Russia, Rostov-on-Don, Russian Federation

${ }^{5}$ Associate Professor of the Department of Constitutional and Administrative Law, South Ural State University, Candidate of Historical Sciences

${ }^{6}$ Regional service of state construction supervision of the Rostov region, head of the sector, Rostov-on-Don, Russian Federation
} 
business, reducing excess pressure on legal entities of different legal forms of ownership and individual entrepreneurs.

Originality/Value: The findings, made by the results of this study, will contribute to improve the effectiveness of the protection of rights and legal interests of business entities during the supervisory activities subjects of public administration.

Keywords: mandatory requirements, regulatory policy, deregulation, control and supervisory activities.

JEL Classification Codes: K2, O29.

Paper type: Scientific article.

Acknowledgment: The study was carried out as part of the research work of the state assignment by the Russian Academy of National Economy and Public Administration under the President of the Russian Federation No. 12.25 on the topic: "Modern approaches to the formation of legal support for reforming control and supervisory activities."

\section{Introduction}

At the present stage, it seems necessary to study the legal regulation of social relations on the basis of the category of legal structure as a legal model formed by legal means, the combination of which, in their systemic interaction, ensures the implementation of certain socially useful functions. The formation of legal structures is a reaction of the state to the needs of a certain state of the socio-economic environment. State control and supervisory activities are no exception: the growing economic costs of its implementation and the need to remove obstacles to business and investment have stimulated the creation of new legal structures, one of which is the legal structure of mandatory requirements.

This circumstance is due to the reform of the system of state control and supervision announced by the Prime Minister in January 2019, within the framework of which the task is not only to update the control and supervisory mechanism, but in fact to create a new model of it that meets modern political and legal requirements. The concept of the "regulatory guillotine" based on it implies the need to take stock of all the mandatory requirements for business entities in order to eliminate outdated ones from legal regulation that do not correspond to modern realities, but only create unnecessary, excessive barriers for the progressive development of the socioeconomic sphere. According to the Ministry of Economic Development and Trade, the current regulations contain over two million mandatory requirements.

Moreover, among them there are still those that were adopted during the Soviet era. Given the current level of technological development, this is one of the main obstacles to business development, while the key goal of these requirements - the safety of people, is not achieved. That is why the Government has decided to carry out a "regulatory guillotine". This event was included in the Main directions of activities of the Government of the Russian Federation for the period up to 2024, 
which in order to comprehensively update the mandatory requirements, it is planned to implement the "regulatory guillotine" as an update of all mandatory requirements adopted earlier than mid-2010.

It is characteristic that in the Decree of the President of the Russian Federation of May 7, 2018 No. 204 "On national goals and strategic objectives of the development of the Russian Federation for the period up to 2024", the reform of control and supervisory activities was not declared as an independent strategic task, however, already in the Address to the Federal At the meeting of February 20, 2019, the President of the Russian Federation drew attention to the need to reform control and supervisory activities, noting that all currently existing regulatory acts in control and supervisory activities should end in 2021, they should be replaced in two years by documents corresponding to modern requirements. The reform of control and supervisory activities was also prolonged in the Address of the President of the Russian Federation to the Federal Assembly of January 15, 2020, in which he called for the completion of the reform of control and supervisory activities, thereby making the work of business more convenient and easier.

The authors of this study put forward a hypothesis according to which the formation of a legal model of control and supervisory activity is formed in a combination of deregulation (the concept of "regulatory guillotine") and regulation (construction of mandatory requirements). The regulation is based on two laws - "On mandatory requirements" and "On state control (supervision) and municipal control in the Russian Federation", the drafts of which are under consideration in the State Duma of the Russian Federation.

The object of the research is public relations in the field of public regulation of economic activity. The subject of the research is legal norms, including design norms that form the legal structure of mandatory requirements, and the accompanying legal doctrine.

\section{Theoretical Foundation and Methodology}

The theoretical basis of the research was formed by scientific works in the field of legal policy in general, and regulatory policy, in particular, among which the works of P.A. Davydov (2007), O.Y. Rybakov and S.V. Tikhonova (2016) and others. The study is also based on works in the field of legal regulation of control and supervisory activities by T.Y. Khabrieva and J. Marcoux (2011), A.I. Stakhov (2015) and others.

The analysis of the degree of elaboration of the investigated problematics showed that today in the legal doctrine there are no comprehensive studies devoted to the legal construction of mandatory requirements. Separate considerations on this issue take place in the framework of analytical work on control and supervisory activities. In this regard, we believe that it is necessary to conduct a comprehensive study, due to the above goals and objectives, as well as the subject area. 
Empirical basis of research was made normative legal acts of the current national legislation, including acts of goal-setting, federal laws and acts of Presidio e coagulant of the Russian Federation and the Russian Federation. The methodological basis of the research was mainly made up of general scientific methods, including: analysis, synthesis, induction, deduction. A special formal legal research method was also utilized.

\section{Results and Discussion}

The key category for this legal regulation model is the category of mandatory requirements, the legal definition of which is proposed in the draft Federal Law "On mandatory requirements" (hereinafter referred to as the draft law).

In accordance with Article 1 of the draft law, the mandatory requirements are the conditions, restrictions, prohibitions established by regulatory legal acts, as well as the obligations of citizens and organizations aimed at protecting the values protected by federal laws. This definition consists of two elements. The first of them is restrictions, prohibitions, obligations (for us, the reasons why the project developers have included conditions in this logical series, leaving their understanding of this concept without explanation; it is obvious that the categories of restrictions, prohibitions and obligations are quite sufficient to determine the legal content mandatory requirements), which are universal instruments of legal regulation, and therefore, obviously, not limited in their application to the scope of control and supervisory activities. As conceived by the developer of the draft law, endowing them with the quality of mandatory requirements is possible through the introduction of a functional feature, which is aimed at protecting the values protected by federal laws.

The foregoing indicates that the proposed as a legal definition of mandatory requirements is based on the methodology for constructing them as a legal structure, which, in turn, opens up the possibility of using this model not only in the field of state control and supervision of the federal level, for which, as follows from the content of the bill, it is intended. This design has an internal potential for application in the legal regulation of any type of public control and supervision, which the developers of the draft law also allow at the level of the constituent entities of the Russian Federation, as well as at the municipal level.

Analysis of the draft law indicates that the potential for legal design of mandatory requirements has not been realized. First of all, this is due to the fact that the draft law does not provide a unified regulatory framework for systemic legal regulation of the establishment and application of mandatory requirements in the mechanism of state control and supervisory activities.

The legal definition of mandatory requirements, being the basis of the corresponding legal structure, obviously does not exhaust its content. The latter includes the entire set of legal institutions and means, the systemic interaction of which ensures the 
implementation of functions defined for the design: bodies that establish mandatory requirements, legal acts that establish these requirements, legal means through which the effectiveness of mandatory requirements is assessed, procedures by which these funds are applied.

In the bill, these issues are settled only in relation to the federal level. For the level of the constituent entities of the Russian Federation and the municipal level, only the principles of establishing and assessing mandatory requirements (part 4 of article 2 of the draft law) are established, which, while defining the general principles of legal regulation in the control and supervisory sphere, still do not exhaust the content of the legal structure. This approach does not exclude the use of legal constructions of mandatory requirements at the regional and local levels, other than those provided by the draft law, and therefore does not fully solve the problem of ensuring the uniformity of legal regulation in this area; this also follows from part 1 of article 2 of the draft law, which limits its subject matter to the legal and organizational foundations for establishing and assessing the application of mandatory requirements contained only in the regulatory legal acts of the Russian Federation.

The definition of mandatory requirements proposed as a legal one is not free from shortcomings, first of all, in terms of its sufficient legal certainty.

The focus on the protection of values protected by federal laws as a functional sign of mandatory requirements has no normative formalization and generally recognized content. The term "value" in Article 1 of the draft law is used to refer to the object of legal protection; This approach is implemented in Article 2 of the Constitution of the Russian Federation, which defines the highest value of man, his rights and freedom. Meanwhile, in federal laws, the use of the term "value" in relation to the object of legal protection does not occur, which means that it will need to be derived analytically - from the meaning of legal regulation, which is clearly confirmed by paragraph 6 of the Methodology for the implementation of the Action Plan ("road map") on the implementation of the "regulatory guillotine" mechanism. The foregoing testifies to the lack of legal certainty of the concept of mandatory requirements proposed in the draft law, which, according to the legal position formed in numerous acts of the Constitutional Court of the Russian Federation, is a significant violation, which is the basis for recognizing the norms as not consistent with the Constitution of the Russian Federation. In addition, in our opinion, the approach implemented in the draft law in principle contradicts the idea of a "regulatory guillotine", because it creates formal prerequisites for establishing mandatory requirements in any area of legal regulation covered by federal laws.

The protection of values determined by law is at the same time a criterion for the admissibility of establishing such requirements, which increases the importance of the normative certainty of the content and types of such values. An important reference point here is set by Part 3 of Article 55 of the Constitution of the Russian Federation, allowing for the possibility of limiting the rights and freedoms of man and 
citizen only to the extent necessary in order to protect the foundations of the constitutional order, morality, health, rights and legitimate interests of others, to ensure the country's defense and state security. We believe that these "target" attitudes just reflect at the essential level those values that the draft law considers necessary to protect by establishing mandatory requirements. It is easy to see this if we turn to the legal tools of the latter: mandatory requirements are nothing more than a legal form of restrictions on subjective rights, since they are represented by prohibitions and obligations, which implies identical grounds for establishing.

The draft law proceeds from the legal polyformism of mandatory requirements. At the same time, the study of the legal definition of mandatory requirements proposed by the bill through the prism of legal forms mediating them reveals a number of serious problems.

In particular, Article 3 of the draft law defines as legal forms of mandatory requirements federal laws, the Treaty on the Eurasian Economic Union of May 29, 2014, acts constituting the law of the Union, international treaties of the Russian Federation that do not require the publication of domestic acts for their application and are in effect in the Russian Federation directly , as well as other legal acts: decrees of the President of the Russian Federation, regulatory legal acts of the Government of the Russian Federation, federal executive bodies and organizations vested in accordance with federal laws with the authority to adopt regulatory legal acts in the established field of activity. The first group of legal forms (international agreements, federal laws) is the basic, starting point for the formation of a system of mandatory requirements, because the admissibility of securing the latter in the forms of other regulatory legal acts should be directly established by law (part 2 of Article 3 of the draft law).

Taking into account the constitutionally predetermined hierarchy of sources of law, it is obvious that compliance with federal laws (according to article 1 of the draft law, only they can determine the "target" grounds for establishing mandatory requirements) can be ensured only in relation to other legal acts, but not international acts in force part 4 of article 15 of the Constitution of the Russian Federation, priority over federal laws. The latter's limitation of the sources for determining values, for the protection of which mandatory requirements can be established, violates this hierarchy, because with this approach, international acts turn out to be tools for the implementation of federal laws. We believe that the legal definition of mandatory requirements should be harmonized with the range of basic legal forms of mandatory requirements by indicating the protection of values established not only by federal laws, but also by those international acts that are included in the basic legal forms of mandatory requirements determined by the draft law.

Another serious problem is as follows. Part 2 of Article 3 of the draft law includes in this system the normative legal acts of the subjects designated as organizations endowed in accordance with federal laws with the authority to adopt normative legal 
acts in the established field of activity (authorized organizations). These subjects are designated here in an extremely abstract way: there are no individualizing signs, including from the point of view of public-legal status; it is clearly indicated only to vest them with the appropriate powers by federal law. From the list of subjects of rulemaking in the field of establishing mandatory requirements given in the specified norm, it becomes clear that authorized organizations are not part of the system of public authorities. Mandatory requirements by their legal nature are norms of law, the form of expression of which is a normative legal act. Thus, the bill provides for the vesting of the authority to adopt normative legal acts on subjects that are not government bodies; any doubts about a different interpretation are excluded by part 3 of article 11 of the draft law, which uses the concept of a regulatory legal act of an authorized organization.

In fact, the bill introduces a new form of exercising public power - entities that are not state authorities, to whom the relevant powers are delegated, which contradicts the foundations of the constitutional system of the Russian Federation, because part 2 of Article 3 of the Constitution of the Russian Federation provides for only three forms of exercising public power: directly by the people, through public authorities, through local governments. Accordingly, the indication in the draft law on the provision of rule-making powers to an organization that is not part of the system of public authorities by federal law has no legal significance, since the latter must comply with the Constitution of the Russian Federation. The participation of entities that do not have a public-law status in the process of establishing mandatory requirements is permissible only in the forms of public discussion, consultation, etc.

The concept of mandatory requirements, enshrined in the draft law, is constructed on the basis of the categories of restrictions, prohibitions, obligations, which are universal instruments of legal regulation.

This approach makes it possible to classify almost any peremptory legal norm as mandatory. This creates the preconditions for "subordination" to the legal regime of the mandatory requirements of any rule-making and law enforcement activity, with the exception of those areas that, by virtue of Part 2 of Article 2 of the draft law, are directly excluded from the subject of its legal regulation. As a result, in order to highlight mandatory requirements in the general array of peremptory norms containing prohibitions and prescriptions, we are forced to turn to the criterion by which part 1 of Article 2 of the draft law determines the subject of its regulation: mandatory requirements are only those requirements whose compliance is assessed within the framework of state control ( supervision), municipal control, prosecution, provision of state and municipal services, conformity assessment, and other forms of assessments and examinations.

The draft Federal Law "On state control (supervision) and municipal control in the Russian Federation" under state control (supervision), municipal control understands the activities of control and supervisory bodies aimed at preventing and suppressing 
harm (damage) to life, human health, morality, rights and legitimate interests of citizens and organizations, harm (damage) to animals, plants, the environment, defense of the country and state security, cultural heritage sites, other legally protected values, carried out within the powers of these bodies by preventing the risks of harm (damage) protected by law values, assessing compliance by citizens and organizations with mandatory requirements and identifying their violations, taking measures provided for by the legislation of the Russian Federation to suppress the violations identified, eliminate their consequences and (or) to restore the legal status that existed before such violation mandatory requirements.

Thus, the concept of mandatory requirements is given by defining them as an object of control and supervisory activities, which, in turn, is defined through the concept of mandatory requirements.

The rest of the forms of assessing mandatory requirements specified in the draft law prosecution, provision of state and municipal services, conformity assessment, other forms of assessments and examinations - add even greater uncertainty to the concept of mandatory requirements. Legal liability is not limited to administrative liability; having excluded criminal liability from the subject of legal regulation (at least this is how one can interpret the indication that the bill does not apply to mandatory requirements in the field of combating crime), financial liability (including tax, budget, banking), the bill actually left in this subject other industry-specific types of liability, including civil law. As a result, from the point of view of the draft law, the mandatory requirements may include civil legal norms, the observance of which is assessed when recovering losses or forfeit; we believe that from the point of view of the essence of control and supervisory activities, this conclusion can hardly be recognized as correct. The indication of other forms of assessments and examinations finally blurs any boundaries between the actual mandatory requirements and peremptory norms that are not related to those.

\section{Conclusions}

Thus, as a result of the study, the hypothesis put forward has been proved, the essence and content of mandatory requirements have been determined, the values of mandatory requirements for the efficiency of economic activity have been established, trends in the formation of the legal structure of mandatory requirements have been identified.

Today, there is a significant increase in requirements for the formation and implementation of state regulatory policy. This circumstance is due to the reform of the system of state control and supervision announced by the Prime Minister in January 2019, within the framework of which the task is not only to update the control and supervisory mechanism, but in fact to create a new model of it that meets modern political and legal requirements. The concept of the "regulatory guillotine" based on it implies the need to take stock of all the mandatory requirements for business entities 
in order to eliminate outdated ones from legal regulation that do not correspond to modern realities, but only create unnecessary, excessive barriers for the progressive development of the socio-economic sphere.

In general, the analysis of the current legislation demonstrates an active process of forming legislation on mandatory requirements. At the same time, the concept of mandatory requirements proposed in the draft law in no way reflects the essence of this legal phenomenon from the point of view of legal regulation of control and supervisory activities. The signs of mandatory requirements fixed in the draft law directly, as well as the signs of mandatory requirements derived from the meaning of the legal regulation it proposes do not allow them to be isolated in the array of peremptory norms that form Russian law, and therefore do not allow ensuring legal certainty in the issue of the substantive basis of control and supervisory activities

\section{References:}

BRM. 2015. Better Regulation Framework Manual. Practical guidance for UK Government Officials. Available online: https://www.gov.uk/government/uploads/system/uploads/attachment_data/file/ 583871/bis-13-1038-Better-regulation-framework-manual.pdf .

Davydov, P.A. 2007. The concept and characteristics of subjects of legal policy. Leningrad Legal Journal, 4.

Khabrieva, T.Y., Marku, J. 2011. Administrative procedures and control in the light of European experience. Moscow.

Martynov, A.B. 2009. Administrative and supervisory production: concept, essence and string of tours. Bulletin of Voronezh State University, Series "Law," 2.

Martynov, A.V. 2010. Administrative supervision in Russia: theoretical foundations of construction. Moscow.

Nozdrachev, A.F. 2017. Reform of state control (supervision) and municipal control. Journal of Russian Law, 9.

Robinson, W. 2016. Renegotiation by the United Kingdom of its constitutional relationship with the European Union. Issues related to Competitiveness and Better LawMaking. Available online: http://www.europarl.europa.eu/supporting-analyses .

Rybakov O.Y., Tikhonova S.V. 2016. Information risks and the effectiveness of legal policy. Journal of Russian law, 3.

Stakhov, A.I. 2015. On the allocation of administrative and procedural law to an independent branch of the law system of the Russian Federation. Bulletin of the University named after O.E. Kutafin (Moscow State University), 8.

Zyryanov, S.M. 2010. Administrative supervision. Moscow, Publishing House "Jurisprudence". 